\title{
Developing Technology of Obtaining wire from High Alloyed Alloys Al-REM System Using the Methods of Combined Treatment
}

\author{
Denis S. Voroshilov*, \\ Sergey B. Sidelnikov and Edward A. Rudnitsky \\ Siberian Federal University \\ 79 Svobodny, Krasnoyarsk, 660041, Russia
}

Received 14.11.2014, received in revised form 12.01.2015, accepted 06.02.2015

This article presents the results of mechanical tests of the properties of wire from alloys of Al-REM system obtained by methods of combined rolling-extruding and combined casting and rollingextruding.

Keywords: combined processes, rolling, extruding, drawing, wire, mechanical properties.

\section{Разработка технологии получения проволоки из высоколегированных сплавов системы Al-P3М с использованием методов совмещенной обработки}

Д.С. Ворошилов, С.Б. Сидельников, Э.А. Рудницкий Сибирский федеральный университет Россия, 660041, Красноярск, пр. Свободный, 79

В статье представлены результаты механических испытаний свойств проволоки из сплавов системы Al-P3М, полученных методами совмещенной прокатки-прессования и совмещенного литья и прокатки-прессования.

Клчюевые слова: совмещенные прочессы, прокатка, прессование, волочение, проволока, механические свойства.

Deformed lengthy semi-finished products as wire, rods, rolled wire of technical aluminum and its alloys widely used for the manufacture of electro technical products. Recently, there was a requirement in deformed semi-finished products of aluminum alloy with rare earth metals (REM), with enhanced

(C) Siberian Federal University. All rights reserved

* Corresponding author E-mail address: d.s.voroshilov@gmail.com 
strength properties and heat resistance. Therefore, they are widely used for production electrical conductors for aircraft, operating at elevated temperatures (up to $250^{\circ} \mathrm{C}$ ).

For the manufacture of wire of these alloys used multilateral-stage technology, including 17 technological conversions. This led to the high cost of semi-finished products due to labor-intensive production and the large amounts of energy. In recent years have development of technology including getting cast billets in an electromagnetic crystallizer (EMC) and its subsequent processing by methods of metal forming, for example, with using combined rolling-extruding (CRE). It is also expedient to use the method of combined casting and rolling-extruding (CCRE), characterized by minimal laborintensive and energy-intensive of the process production of lengthy semi-finished products of small cross-section [1].

Using methods of CRE and CCRE to produce such press articles of hard alloys, for example, alloys system Al-REM studied little and requires further experimental and theoretical studies. In addition, the available scientific and technical literature provides evidence about the advantages of the scheme process rolling-extruding with one driving roll, which requires a more depth study, since the selection implementation scheme of process combined treatment, especially for high-strength alloys is a determining.

Task of studying metal forming of the model sample subjected rolling-extruding with one driving roll, was solved using the method of coordinate grid. The resulting change in shape of billet after the deformation of the metal was compared with not completely deformed sample receipted with scheme CRE with two driving rolls.

Analyzing metal forming can be noted that at the moment of maximum compression during rolling the side walls of caliber have full contact with side faces of the billet, as in the case with two driving rolls. However, after leaving the area of the maximum compression during rolling seen backlog of metal from the surface of non-driven roll because of the different speeds of the metal flow on contact with roll.

In this regard, have been conducted studies of realizability process CRE with one driven roll and the results are compared with realizability of the process, when both rolls are driven.

Realizability of the process was evaluated by the coefficient $K_{y}$ :

$$
K_{y}=\frac{P_{1}-P_{2} \lambda}{P_{1}} \cdot 100 \%
$$

Where $P_{1}$ - force supplied by rolls of friction, $P_{2}$ - the force required to extrude the metal through a hole matrix, $\lambda$ - coefficient characterizing the ratio of the current metal speed to the speed of rolls.

This coefficient obtained from the condition of powers connected by rolls and spent on extrusion of metal. The calculation results are shown in Fig. 1. It was found that the coefficient of realizability $K_{y}$ for process CRE with one driven roll on average lower by $20 \%$ compared to scheme with two driving rolls.

However, studies have shown, that the application of given treatment scheme is appropriate when the task to reduce energy-power expenditures of the process. To reduce unevenness deformation of the metal, and to guarantee realizability of the process CRE it is advisable application of the process scheme with two driven rolls, and the increase in energy costs for extruding metal can be compensated by reducing the degree of deformation (draw ratio). 


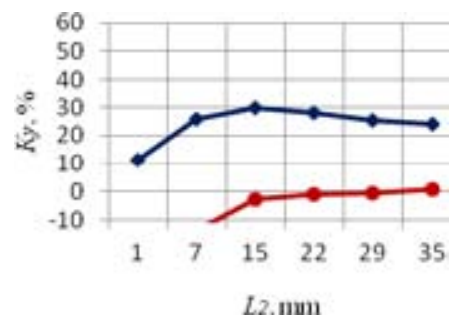

a

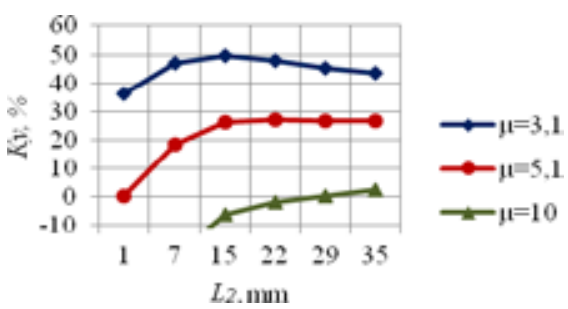

b

Fig. 1. Changes in the coefficient realizability of the process CRE for alloy system Al - REM depending on the draw ratio $\mu$ and the value of removal matrix from total axis of rolls $L_{2}$ with the degree of deformation during rolling $\varepsilon=50 \%$ : a - with one driven roll; $\mathrm{b}-$ with two driven rolls

Studies were conducted on experimental alloy containing such REM as $C e, L a, P r$ in the amount of 7-9\%. The chemical composition of the alloy was close to the alloy mark 01417 , regimented by TC 1-809-1038-96.

Varied factors were the following: temperature $(T)$, strain rate $(\xi)$ and draw ratio $(\mu)$. Experimental studies were conducted in the following order. At the first stage using the EMC received cast billets with maximum diameter to $17 \mathrm{~mm}$ for subsequent CRE. An analysis of the microstructure of the obtained ingots was found, that the structure is an aluminum solid solution dendrites and eutectic ( $\alpha$ $+\mathrm{Al}_{4} \mathrm{M}$ ), where $\mathrm{M}$ - mixture of metals, composed of cerium and lanthanum [2]. For measuring power parameters installation was equipped with tensometric equipment, allowing fixing the force on the rolls and the matrix. As a result of experimental studies were obtained rods diameter 5, 7 and $9 \mathrm{~mm}$ by two methods (CRE and CCRE).

Results of experimental studies on the power parameters of processes CRE and CCRE given in Table 1.

Analysis of the data showed, that the forces acting on the instrument (on rolls and matrix) lower when using the method CCRE, This can be explained by higher temperatures in the deformation center of the metal, and as a consequence, lower values of resistance to deformation of the metal. In this case, maximum efforts shall not exceed values $550 \mathrm{kN}$, that in comparison with efforts of the traditional extruding on horizontal hydraulic presses the same semi-finished products with given technological parameters lower in 2-3 times.

Then were held measurements of electrical resistance and mechanical properties on rods obtained by different technologies. P The results showed that the values of these parameters correspond TC 1-809-1038-96.

Also in the development of new technical solutions the actual problem is decision of questions related to the automation of the process, improve the quality of press-articles and cooling of the working instrument. To implement these methods have been developed new technical solutions for combined treatment of alloys system Al-REM, protected by the patents RF № 101390 [3], № 102313, № 102542. The use of these devices improves performance of the process rolling-extruding and quality of obtained press-articles.

With the use of new technological solutions developed technology of obtaining wire of electrotechnical purpose from studied alloy system Al-REM with using method CCRE for obtaining 
Table 1. Results of experimental studies on the power parameters of experimental alloy by methods CRE and CCRE

\begin{tabular}{|c|c|c|c|c|c|c|c|}
\hline \multicolumn{8}{|c|}{ CRE } \\
\hline \multirow{2}{*}{\multicolumn{2}{|c|}{ Parameters }} & \multicolumn{3}{|c|}{$T=480^{\circ} \mathrm{C}$} & \multicolumn{3}{|c|}{$T=550^{\circ} \mathrm{C}$} \\
\hline & & $\mu=3,1$ & $\mu=5,1$ & $\mu=10,0$ & $\mu=3,1$ & $\mu=5,1$ & $\mu=10,0$ \\
\hline \multirow{2}{*}{$\xi=0,74 \mathrm{sec}^{-1}$} & $\mathrm{P}_{\text {roll, }}, \mathrm{kN}$ & 452,4 & 484,0 & 539,5 & 340,0 & 368,8 & 372,0 \\
\hline & $\mathrm{P}_{\text {matr, }} \mathrm{kN}$ & 387,1 & 445,8 & 549,4 & 358,9 & 402,2 & 493,2 \\
\hline \multirow{2}{*}{$\xi=1,49 \mathrm{sec}^{-1}$} & $\mathrm{P}_{\text {roll }}, \mathrm{kN}$ & 410,1 & 453,8 & 502,7 & 312,4 & 346,6 & 350,4 \\
\hline & $\mathrm{P}_{\text {matr, }} \mathrm{kN}$ & 377,6 & 425,7 & 539,1 & 339,5 & 368,4 & 469,5 \\
\hline \multicolumn{8}{|c|}{ CCRE } \\
\hline \multirow{2}{*}{\multicolumn{2}{|c|}{ Parameters }} & \multicolumn{3}{|c|}{$T=750^{\circ} \mathrm{C}$} & \multicolumn{3}{|c|}{$T=780^{\circ} \mathrm{C}$} \\
\hline & & $\mu=3,1$ & $\mu=5,1$ & $\mu=10,0$ & $\mu=3,1$ & $\mu=5,1$ & $\mu=10,0$ \\
\hline \multirow{2}{*}{$\xi=0,74 \mathrm{sec}^{-1}$} & $\mathrm{P}_{\text {roll, }} \mathrm{kN}$ & 372,5 & 384,3 & 397,3 & 291,3 & 305,8 & 321,9 \\
\hline & $\mathrm{P}_{\text {matr, }} \mathrm{kN}$ & 267,1 & 298,0 & 367,4 & 230,9 & 254,2 & 315,2 \\
\hline \multirow{2}{*}{$\xi=1,49 \mathrm{sec}^{-1}$} & $\mathrm{P}_{\text {roll, }}, \mathrm{kN}$ & 350,2 & 376,8 & 382,5 & 262,2 & 281,9 & 303,4 \\
\hline & $\mathrm{P}_{\text {matr, }} \mathrm{kN}$ & 225,2 & 255,7 & 333,1 & 187,5 & 215,7 & 269,5 \\
\hline
\end{tabular}

billet under subsequent drawing to a diameter of $0,3 \mathrm{~mm}$. It should be noted, that the plasticity of obtained billet was sufficient, therefore not required any intermediate annealing.

With the use of new technical solutions developed the technology of obtaining wire of electro technical purpose from studied alloy Al - REM system with using method CCRE for obtaining billet at followed drawing. The results obtained in experimental studies of batch deformed semi-finished products were transferred to the LLC STC «Aviaspetssplav» (Moscow) for obtaining the wire of specified diameters for electrical conductors used in the production of aircraft. Documented that the results of scientific research consisting in the development of technologies for obtaining long semifinished products from high-alloyed $\mathrm{Al}$ - REM system alloys intended for production the wire of electro technical purpose implemented in production and raise its effectiveness.

Thus, the result of research using new technological solutions developed the technology of production electro technical wire from high-alloyed Al - REM system alloys based on the application of the methods of combined treatment. Application of this technology can significantly reduce production costs by reducing the number of technological stages and increase the output of suitable at the expense of obtaining quality products of a small cross section.

This work was performed under Government Decree RF №218 «On measures of state support for the development of cooperation of Russian higher education institutions and organizations, which realize complex projects to develop high-tech production » in accordance with the agreement Russian Ministry of Education №13.G25.31.0083 to create a high-tech production on the theme « Development of technologies for obtaining aluminum alloys with rare earth, transition metals and high-performance equipment for production of electrotechnical wire rod», under grants within «Development program of SFU on 2007-2010 years», as well as contracts with LLC «RUSAL ETC». 


\section{References}

[1] Sidelnikov S.B., Dovzhenko N.N., Zagirov N.N. Combined methods of treatments of nonferrous metals and alloys: a monograph. M.: MAKS Press, 2005. P. 344.

[2] Sidelnikov S.B., Dovzhenko N.N., Baranov V.N. and others // Bulletin of the Magnitogorsk State Technical University named after G.I. Nosov. Magnitogorsk, 2011. №.4. P. 40-43.

[3] Sidelnikov S.B., Dovzhenko N.N., Belyaev S.V. and others. A device for the continuous rolling and extrusion. Patent RF № 101390. Publ. 20.01.11 / Bul. № 2. 